\title{
Библиография:
}

OSIPOVA, È. F. (2019): Putešestvije idej. Iz istorii kul'turnych svjazej Rossii i SŠA. Sankt-Peterburg.

\section{К сопоставительному анализу синтаксических терминов}

БЕРГЕР, О.: Синтаксические термины в русском и чешском языках: сопоставительный аспект (на материале выбранных терминов). Brno: Masarykova univerzita, 2021. 141 s. ISBN 978-80-210-9807-7.

Терминология - это один из самых быстроразвивающихся пластов лексики. По подсчетам специалистов, термины составляют от 50 до 8о \% новых слов и значений. По некоторым источникам, это значение достигает даже $90 \%$ [SOCHOR 2008]. Лингвистическая терминология является частью метаязыка лингвистики, поэтому ее изучение является актуальным.

В центре внимания автора рецензируемой монографии - это исследование русской и чешской синтаксической терминологии на материале выбранных терминов. Синтаксическая терминология современного русского и чешского языка является весьма развитой. В последнее время вошло в обиход много синтаксических наименований. Основная концепция проводимого автором научного исследования состоит в том, что даже базовые синтаксические термины трактуются по-разному в русской и чешской синтаксических школах. Несмотря на сходство синтаксического строя русского и чешского языков, несмотря на близость и взаимовлияние русской и чешской синтаксической школы, зачастую рассматриваемые явления описываются с помощью разных терминов, или схожие термины отличаются объемом значения. Таким образом, целью исследования автора настоящей работы стал сопоставительный анализ важнейших русских и чешских синтаксических терминов на материале работ русских и чешских русистов и чешских богемистов. Каждая группа содержит материал как из раньше изданных работ (вышедших приблизительно в середине прошлого столетия), так и из работ изданных в последнее время; их список, послуживших для выборки, представлен в начале каждой главы монографии. 
В введении (Введение, [BERGER 2021, 7-11]) кратко и наглядно излагается предмет и замысел исследования автора, упоминаются избранные методы и источники, используемые для получения материала для анализа.

В первой главе (История изучения термина. Основные теоретические понятия терминоведения, [BERGER 2021, 12-40]) автор сначала занимается историей изучения терминов в русском и чешском языкознании, разбирает его принципы и направления. Изучением термина, терминосистемы, терминологии занимаются две дисциплины - терминоведение и терминография, значение и содержание которых автор в настоящей главе объясняет. Традиционно выделяется несколько терминологических школ - венская, советская, пражская, канадская, немецкая и скандинавская. По словам автора, ученые пришли к выводу, что упомянутые школы имели схожие взгляды на теорию терминоведения, однако существенное отличие заключается в том, что они написаны на разных языках и применены к разным отраслям науки. В настоящей главе характеризуются свойства и признаки термина, уточняются такие понятия, как терминологическое поле, терминология, терминологическая система. В центре внимания автора находится также проблематика синонимии и вариантов терминов; с этим можно встретиться в работах русских лингвистов. Однако разграничение осложняется тем, что у терминоведов нет единого мнения относительно синонимии и вариативности в терминологии. Автор настоящей работы придерживается концепции С. Д. Шелова, который выделяет в своей статье О вариативности и синонимии в терминологии [Izvestija... 2014, 3-17] свои подходы. Автором приводятся положения, на которые будет опираться в дальнейшем исследовании.

Одним из сложных вопросов для синтаксистов является проблема словосочетания. Сложности возникают уже при дефиниции этого термина, потому что подход лингвистов к определению словосочетания отличается. Анализу терминов словосочетание и синтагма (с̌. syntagma a slovní spojení) в русских и чешских грамматиках, не только с точки зрения их содержания, но и с точки зрения их взаимоотношения, посвящена вторая глава (Словосочетание и синтагма в русских и чешских грамматиках, [BERGER 2021, 41-53]). Термины анализируются постепенно: сначала в работах русских лингвистов, затем в работах чешских и словацких русистов, наконец, в работах чешских богемистов. Прежде разбирается история изучения словосочетания. Данный термин ввел в научный обиход А. Х. Востоков. В первых оригинальных русских грамматиках уделялось большое внимание описанию сочетаний слов разных частей речи, но словосочетание как особая синтаксическая единица не рассматривалось. Новый поворот связан с именем Ф. Ф. Фортунатова, представителя Московской фонетической школы и формального направления 
в синтаксисе. Ф.Ф.Фортунатов рассматривал словосочетание, как самостоятельную синтаксическую единицу, считал его главным предметом изучения синтаксиса. Что касается термина синтагма, подчеркиваются отличия русского и чешского понимания: в русской традиции содержание термина понимается первично в фонетическом смысле, только вторично в смысле синтаксическом, между тем как в чешской традиции это синтаксическая единица. Автор рецензируемой монографии не считает термины синтагма и словосочетание терминами идентичными, пытается подытожить различные взгляды как на их понимание, так и на их взаимоотношения в русской и чешской традиции. В чешской русистской традиции синтагма считается термином синтаксическим, между тем как словосочетание - термином лексическим. Наоборот, чешские термины slovní spojení, větná dvojice, skladební dvojice, syntagma понимаются в произведениях чешских богемистов как синонимы. Значит, русский и чешский термин синтагма/syntagma не являются полными эквивалентами. Различие наблюдается как в объеме понятий, обозначаемых терминами, так и на формальном уровне.

Один из важнейших вопросов синтаксиса - это вопрос о синтаксических отношениях. В третьей главе (Типь синтаксических отношений и средства их выражения, синтаксические связи, [BERGER 2021, 54-75]) разбирается связанная с этим вопросом терминология на материале избранных грамматик русского и чешского языка. В работах русских синтаксистов встречаются термины синтаксические связи и синтаксические отношения. Оба термина сначала использовались как синонимы, однако в настоящее время появилась тенденция различать их, и даже некоторым способом их противопоставлять. Синтаксические отношения связывают в первую очередь с планом содержания, а синтаксические связи с планом выражения. В работах чешских русистов и богемистов последовательно различаются два термина - syntaktické vztahy (синтаксические отношения) и syntaktické prostředky (средства выражения синтаксических отношений, синтаксические связи). Указанные русские термины и их чешские эквиваленты представляют собой терминологическую проблему.

Синтаксические отношения в словосочетании не идентичны с синтаксическими отношениями в предложении; для предложения типичны предикативные отношения. Синтаксические связи в работах русских русистов обычно делятся на сочинительные и подчинительные, в рамках подчинительных связей выделяются согласование, управление, примыкание.

В случае чешских русистов упоминается концепция Р. Мразека, который рекомендует выделять пять типов синтаксических отношений: предикацию, детерминацию, координацию, аппозицию и парентезу. Он считает, что парентезу (нулевое отношение) и аппозицию (особую разновидность детерминации) 
можно исключить из разновидностей синтаксических отношений, однако выделяет еще один тип - предикативную детерминацию - вид отношений, которые возникают в т. наз. предикативном атрибуте (чеш. doplňku). Р. Зимек понимает оба термина в концепции, типичной для русской синтаксической школы; вместо термина синтаксические связи употребляет термин способы выражения синтаксических отношений. Тщательно описана терминологическая я система Г. Флидровой и С. Жажи в учебном пособии по русскому синтаксису [FLÍDROVÁ, ŽAŽA 2013]. Авторами указываются термины-синонимы: сочинительная связьсочинение, координация; подчинительная связь - подчинение, детерминация. В настоящей главе упомянуты также термины паратаксис и гипотаксис, употребляемые прежде всего в чешской традиции; с их помощью обозначаются формальные средства выражения для сочинительных и подчинительных отношений.

Терминологическая система чешских богемистов представлена в работах $\Phi$. Копечного, В. Шмилауэра, М. Грепла и П. Карлика, а также и в третьем томе т. наз. академической грамматики чешского языка от 1986 г. (авторы Ф. Данеш, 3. Главса, М. Грепл). М. Грепл и П. Карлик в их совместном издании [GREPL, KARLÍK 1986] выделяют сочинение и подчинение, пользуясь терминами subordinační vztah - subordinace - podřad’ování; koordinační vztah - koordinace přrirad’ování.

В настоящей главе автор сосредоточилась на совпадениях и несовпадениях концепций русской и чешской синтаксической школы. Точно здесь описываются различия в понимании анализируемых терминов.

Самой пространной является четвертая глава (Члены предложения, [BERGER 2021, 76-120]), содержащая подробные изложения, в которых сравнивается концепция главных и второстепенных членов предложения, как это трактуется в русской и чешской синтаксической традиции. Настоящая глава распадается на четыре раздела: члены предложения, главные члены предложения (подлежащее, сказуемое), второстепенные члены предложения (дополнение, определение, приложение, обстоятельство), члены предложения, выделяемые отдельными авторами (семантический субъект, дуплексив). В каждом разделе излагаются подходы представителей обеих синтаксических школ, в конце каждого раздела на основании проведенного анализа автор приводит выводы своего исследования.

В вступительном слове в виде исторического экскурса объясняется происхождение названий главных и второстепенных членов предложения и их применение в грамматиках (начиная с А. А. Барсова по современность). Теория членов предложения показана на разборе терминов, встречающихся в грамматических произведениях XX века, особенно с указанием на соответствующие словарные 
статьи в Словаре лингвистических терминов О. С. Ахмановой [ACHMANOVA 2004] и в Novém encyklopedickém slovníku češtiny [KARLÍK, NEKULA, PLESKALOVÁ 2016], далее в работах оломоуцкого русиста В. Словака [SLOVÁK 2017; SLOVÁK 2018; SLOVÁK 2020]. Автор выделяет пять признаков для классификации членов предложения.

Одним из принципиальных вопросов синтаксической теории является вопрос о главном члене односоставного предложения. Чешский русист П. Адамец, автор данного раздела в учебнике [KUBÍK 1982], рекомендует применять термин единый главный илен односоставного предложения. Этот термин выделяется, как правило, также в более современных русских учебниках по синтаксису. Одновременно он приводит его классификацию на основании его частеречной принадлежности; всего выделяет восемь типов. В учебнике Г. Флидровой и С. Жажи [FLÍDROVÁ, ŽAŽA 2013] для наименования единого главного члена односоставного предложения используется термин предикат. В этом учебном пособии термины «односоставные» и «двусоставные» ввиду их неточности не употребляются, так как сказуемое «двусоставного» и «единый главный член односоставного предложения» выполняют ту же функцию. Если предложения не содержат подлежащную часть, обозначаются они как бесподлежащные (бессубъектные, не односоставные) и употребляется вышеупомянутый термин «предикат». Для чешской синтаксической традиции характерен переход от противопоставления односоставного предложения к двусоставному на основании противопоставления предложений подлежащных и бесподлежащных. Этим объясняется разница в терминах, используемых для обозначения единого главного члена предложения. В связи с этим упоминается учебник по чешскому синтаксису М. Грепла и П. Карлика [GREPL, KARLÍK 1986]. Его авторы выделяют в односоставных предложениях также один главный член предложения - př́sudek.

Подобно описаны термины для наименования второстепенных членов предложения. Подчеркиваются различия в теории русской и чешской синтаксической традиции, особенно это касается дополнения и обстоятельства: обращено внимание на их неоднозначное определение. При анализе обстоятельства приведен ряд уточняющих терминов, которые находятся во втором томе т. наз. пражской академической грамматики русского языка [BARNETOVÁ 1979]. Типы и подтипы обстоятельств выделяются на основании выраженного ими значения, причем различаются мельчайшие оттенки значения.

В работах чешских лингвистов (русистов и богемистов) анализируемые термины можно употребить не только для обозначения второстепенных членов предложения, а также и для определения типов придаточных предложений; это для русской лингвистики нетипично. Кроме того, для чешских работ 
(русистических и богемистических) характерно употребление синонимичных терминов (ср.: дополенение - объект, определение - атрибут, př́slovečné určeníadverbiale, podmět - subjekt, př́vlastek - atribut, shoda - kongruence...) и при выделении новых членов предложения (ср.: doplněk - predikativní atribut, семантический субъект - косвенное дополнение).

В заключении настоящей главы подчеркиваются отличия и расхождения в понимании всех членов предложения. Далее излагаются термины членов предложения, характерные для чешской русистики и богемистики (cp.: subjektové určení // sémantický subjekt и нек. др.); синтаксисты, таким образом, стараются решить вопрос синтаксического синкретизма и уточнить классификацию членов предложения. Далее это чешский doplněk; в русской синтаксической традиции этот термин не употребляется (этот член предложения обозначается по-разному, например, предикативный атрибут, сказуемостное определение, предикативный определитель, второе сказуемое, присказуемое, копредикат). Большинством русских лингвистов не считается особым членом предложения и рассматривается, как именная часть предиката. Чешские русисты употребляют термин дуплексив; термин был заимствован от русской лингвистки Л. D. Чесноковой [ČESNOKOVA 1973].

В конце обсуждаемой монографии (Общие выьводы, [BERGER 2021, 121-123]) автор полагает, что исследуемые микросистемы синтаксических наименований словосочетание, синтаксические отношения, члены предложения являются самыми важными в области синтаксической терминологии; в русском и чешском языке они точно разработаны. В результате сопоставительного анализа были выявлены различия в трактовке и функционировании важнейших общеупотребительных синтаксических терминов. Сопоставительный анализ наметил места возможной интерпретации при изучении синтаксиса и при переводе данных синтаксических названий.

Следует резюме на английском (Summary, [BERGER 2021, 124-128]) и на чешском языке (Resumé, [BERGER 2021, 129-133]). В конце отпечатаны список литературы (Библиография, [BERGER 2021, 134-140]), список употребляемых сокращений (Список сокращений, [BERGER 2021, 140-141]) и список таблиц (Список таблии, [BERGER 2021, 140]). Содержание помещено в начале монографии (Оглавление, [BERGER 2021, 5-6]).

Автор предлагаемой работы проанализировала весьма трудную синтаксическую тему на соответствующем специальном уровне. В сопоставительном плане рассмотрела с точки зрения содержания и взаимного отношения избранные термины в русской и чешской синтаксической теории. Работу можно считать ценным вкладом для сопоставительного изучения русского и чешского языков в синхронном плане. Результаты исследования могут быть вкладом для 
дидактики изучения русского языка как иностранного, но могут стать также и теоретическим обогащением для чешской лингвистической русистики.

Алеш Бранднер

\section{Библиография:}

ACHMANOVA, O. S. (2004): Slovar' lingvističeskich terminov. Moskva.

BARNETOVÁ, V. a kol. (1979): Russkaja grammatika 2. Praha.

BERGER, O. (2021): Sintaksičeskije terminy v russkom i češskom jazykach: sopostavitel'nyj aspekt (na materiale vybrannych terminov). Brno.

ČESNOKOVA, L. D. (1973): Semantičeskije tipy členov predloženija s dvojnym otnošenijem. Materialy dlja speckursa. Moskva.

FLÍDROVÁ, H., ŽAŽA, S. (2013): Sintaksis russkogo jazyka v sopostavlenii s češskim. Brno.

GREPL, M., KARLÍK, P. (1986): Skladba spisovné češtiny. Praha.

Izvestija Rossijskoj Akademii nauk. Serija literatury i jazyka, 2014, № 5 (73), s. 3-17.

KARLÍK, P., NEKULA, M., PLESKALOVÁ, J. (eds). (2016): Nový encyklopedický slovník češtiny. Praha.

KUBÍK, M. (ed.). (1982): Russkij sintaksis v sopostavlenii s češskim. Praha.

SLOVÁK, V. (2017): Neshodný př́vlastek v ruštině a češtině a problematika jeho vymezení. Opera Slavica, 2017, № 2 (27), s. 31-43.

SLOVÁK, V. (2018): Vklad teorii grammatičeskogo sinkretizma v opisanii sintaksičeskogo urovnja jazyka na materiale russkogo $i$ češskogo jazykov. Novaja rusistika, 2018, № 1 (11), s. 27-38.

SLOVÁK, V. (2020): Synkretizmus větných členů v ruštině a češtině. Olomouc.

SOCHOR, K. (2008): Přiručka o českém odborném názvosloví. Praha. 
